\title{
Science of Advance in Aqua Farming Study of Food and Feeding Habits of Jumbo Tiger Shrimp, Penaeus monodon (Fabricius, 1798) from Parangipettai, South East Coast of India
}

\author{
D Varadharajan* and P Soundarapandian \\ Faculty of Marine Sciences, Centre of Advanced Study in Marine Biology, Annamalai University, Parangipettai-608 502. Tamil Nadu, India
}

\begin{abstract}
Food is required to produce energy to maintain in order to live and improve food habits of the species. The land food production is influences the disruptions and distribution is a major source of hunger and malnutrition. The people had a starvation and finally are attaining food deficiency diseases. The food from marine origin is high when compared in land food. Though, the marine food items can occur to shortage when over-capitalized capture fisheries, climate change and pollution lead to resource depletion. Aquaculture is playing an important mechanism for poverty alleviation and food security. An ectothermic animal of shrimp P. monodon are important for aqua farming practices in all over of the world. Rearing species the farmers are responsible for providing access to adequate food to eliminate hunger and malnutrition. Food is a major source of energy budget. Which food is habitually like a rearing organism is a difficult to judge. Successful farming a thorough knowledge about food and feeding habits of the rearing organisms is very important ones. In the present study, food and feeding habits of $P$. monodon were undertaken respectively. Analysis of the examined gut contents revealed that Crustacean, Fish, Phytoplankton, Zooplankton, Amphipods, Isopods, Polychaetes, Bivalves, Gastropods, Nematodes, Supplementary feed, Detritus, Sand and Miscellaneous as a main food items were observed in the $P$. monodon from Parangipettai coastal farming environment. The food and feeding habits of shrimp are different from month to month. Young ones of $P$. monodon it consists of preys mainly on plant origin and adults are preferred preys on animal origin. The results clearly indicate that, $P$. monodon is a considered highly omnivorous detrivore. In the information are useful for the shrimp culture with intensive, semi-intensive and mass scale practices in anywhere of the world.
\end{abstract}

Keywords: Giant tiger shrimp; Feeds; Habits; All planet science; Leader of aqua farming

\section{Introduction}

The black tiger shrimp of the genus Penaeus, species monodon belonging to family Penaeidae. The P. monodon are found in the marine regions which includes freshwater and salt water. Morphologically are simply identified shrimp of $P$. monodon is necessitate for culture aspects in all over of the world. In the recent health scenario the peoples are affected by natural disasters such as droughts, tornados, marketing which include manmade disasters even war and result in shortages of food. If searching the food from other planet now it is not possible. Still, the humans are exploiting more than five hundred species as food resources from the marine environment. But, the food from land is only fourteen where using commercial purposes. Since, the peoples are looking in aquatic food especially seafood items. Aqua farming candidate species of the shrimp $P$. monodon are useful for details information on its food and feeding habits. It is very much useful for without disease of successful culture and export trade. Food is one of the substances like solid, liquid and gas, usually eaten or drunk by living things. It is an essential component to shrimp life cycles. The nutrition of shrimp is gain energy from feeding habits. There are main controllers or factors of birth, promote growth, metabolism, catabolism, maturity, breeding, survival, predatory activities; maintain body temperature, healthy weight and more. Feeding habits of shrimp is depends upon the environmental conditions and slightly vary one place to other places. Individual species alive in particular habitat diet can vary at different periods, similarly the same species occupy in different habitat can vary feeding habits on different types of food [1-4]. Under cultured shrimp is main problem of feed management, mainly influencing the ability, behavior, survive, breeding, physiological and genetic characteristics. The living shrimp are mainly concerns for feeding, while the gain the nutrition of its searching for food [3-5]. Regularly, living shrimps the feeds are need for several precious processes that are vital to survive and make activities. It is essential for cells to perform various functions and maintains body strength, cell division, convey energy to cells, building new cells, repairing body parts, molecules structure, mutation, muscular contractions, functions of hormone, enzyme, nerve impulse conduction, provide stronger immune capability and detect the ability and maintain of proper health from the surrounding regions. The study of the food and feeding habits of shrimp are significantly required for all the function of individual shrimp as well as the population $[2,6,7]$. And are a vital technique to know mechanisms and processes which structure of shrimp assemblages [1,7]. Habitual exercise of the food and feeding habits is provides many information for successful culture management. However, the peculiar information on the food and feeding habits of $P$. monodon is an economically and socially essential in the current economic scenario. The true data on the food and feeding habits is very much useful for the tropic relationship and interactions of shrimp. There is an important of shrimp life history, related research

*Corresponding author: D Varadharajan, Faculty of Marine Sciences, Centre of Advanced Study in Marine Biology, Annamalai University, Parangipettai-608 502, Tamil Nadu, India, Tel: 04144-243223; Fax: 04144-243553; E-mail heartvaradhan@gmail.com

Received July 16, 2013; Accepted September 27, 2013; Published October 08 , 2013

Citation: Varadharajan D, Soundarapandian P (2013) Science of Advance in Aqua Farming Study of Food and Feeding Habits of Jumbo Tiger Shrimp, Penaeus monodon (Fabricius, 1798) from Parangipettai, South East Coast of India. J Aquac Res Development 4: 196 doi:10.4172/2155-9546.1000196

Copyright: $\odot 2013$ Varadharajan D, et al. This is an open-access article distributed under the terms of the Creative Commons Attribution License, which permits unrestricted use, distribution, and reproduction in any medium, provided the original author and source are credited. 
Citation: Varadharajan D, Soundarapandian P (2013) Science of Advance in Aqua Farming Study of Food and Feeding Habits of Jumbo Tiger Shrimp, Penaeus monodon (Fabricius, 1798) from Parangipettai, South East Coast of India. J Aquac Res Development 4: 196 doi:10.4172/21559546.1000196

Page 2 of 8

and management programs. It is a way to understanding of mechanisms and processes which structure of shrimp assemblages. In the research science on superior deals with the food and feeding habits on the culture crustaceans with free disease, the newest champion of edible shrimp P. monodon from Parangipettai shrimp farming environment.

\section{Materials and Methods}

The samples of $P$. monodon collected from culturing shrimp ponds from near in Vellar estuary at Parangipettai coast during between March-2012 to June-2012. After collection, the shrimps were stored in ice boxes and the guts were removed and fixed in $10 \%$ buffered formalin and were analyzed to study the food and feeding habits of this species. It is very difficult to identify the food items species wise due to the nibbling action of mandibles on the food and mastication of food inside the intestine by the action of gastric mill. Average of 157 specimens (size ranged between 7 to $15 \mathrm{~cm}$ and weight 16.5 to $33.1 \mathrm{~g})$ was collected from shrimp ponds during the study period. The gut contents of $P$. monodon were later analyzed in the laboratory. Immediately after the collection the standard length of the shrimp was recorded before removing the gut. They were split open by a pair of scissors. After dissecting of the alimentary system, different components of the gut were recorded with the help of dissecting binocular microscope. The food items were identified up to the family level wherever possible; the assumed prey material was sorted and preserved in $70 \%$ alcohol for further identification [8,9]. The food and feeding habits of the species are measuring different method there using volumetric [10] and occurrence method [11]. In order to help the interpretation of the gut contents analysis, the feeding behavior of the shrimp species under study were occasionally observed and recorded in the aqua farming environment during the field missions $[7,8]$. For identification of phytoplankton, identification manual of [9] was used. Identify the zooplankton by using the references of Kasthurirangan LR and Wickstead $\mathrm{JH}[12,13]$. The polychaetes were identified by using the handbooks of Fauvel P and Berkeley $[14,15]$ and other preys were identified by using standard manuals. The feed composition is measure basis to grade level accurately were using Index of Preponderance and incorporates information of both frequency of occurrence and volume of each prey [16].

\section{Index of preponderance}

$$
I=\frac{V_{I} O_{I}}{\mathrm{O} V_{I} O_{I}} \times 100
$$

Where,

I=Index of preponderance

$\mathrm{V}_{\mathrm{I}}=$ Volume percentage

$\mathrm{O}_{\mathrm{I}}=$ Occurrence percentage

Ó=Summation

\section{Index of relative importance}

The Index of Relative Importance (IRI) was calculated using the formula as

\section{$\mathrm{IRI}=(\mathrm{N}+\mathrm{V}) \mathrm{F}$}

Where,

$\mathrm{N}=$ Number of food items

$\mathrm{V}=$ Volume

\section{$\mathrm{F}=$ Frequency}

\section{Gonado Somatic Index (GSI)}

Gonado somatic Index (GSI) was calculated using the formula

$$
\operatorname{GSI}(\%)=\frac{\text { Weight of } \text { gut }(\mathrm{g})}{\text { Total Weight of shrimp }(g)} \times 100
$$

\section{Feeding Intensity (FI)}

Feeding Intensity (FI) was calculated using the formula

Feeding index of shrimp $=\frac{\text { Number of the shrimp with full gut }}{\text { Total number of the shrimp exa } \text { mined }} \times 100$

\section{Results}

The food items is found in the examined specimen of P. monodon gut were grouped into fourteen different categories namely Amphipods, Isopods, Crustacean, Fish, Phytoplankton, Zooplankton, Polychaetes, Bivalves, Gastropods, Nematodes, Supplementary feed, Detritus, Sand and Miscellaneous (Table 1). During the study period the different food categories were observed. The Index of preponderance, Index of relative importance, Gonado somatic index and Feeding intensity of different food items observed in the gut of $P$. monodon.

\section{Index of preponderance and index of relative importance}

The index preponderance with percentage occurrence of the different food item in conditions of the index relative importance with percentage volume for different month is presented in Tables 1 and 5. Crustaceans are a predominant food item of P. monodon; the examined guts it was occupied for the $1^{\text {st }}$ rank and the Index of Preponderance were maximum of 34.9 during March. $2^{\text {nd }}$ and $3^{\text {rd }}$ rank occupied was in fish and miscellaneous it was observed maximum of 17.2 and 16.8 respectively. The feed compositions were observed in different Index of Preponderance in following the ascending order, Detritus (8.6)>Supplementary feeds (5.92)>Zooplankton (4.12) $>$ Sand (3.23) $>$ Polychaetes (2.05) $>$ Phytoplankton (1.89) $>$ Isopods (1.74) $>$ Gastropods (1.45) $>$ Amphipods (1.11) $>$ Bivalves $(1.03)>$ Nematodes (1.02) (Table 1). The Index of Relative Importance were ranged from 17.86-139.92 in the month of March. The maximum of Index of Relative

\begin{tabular}{|c|c|c|c|c|c|c|}
\hline S. No & Prey items & Occurrence & Volume & $V_{i} Q_{i}$ & 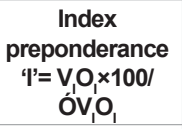 & Grading \\
\hline 1 & Crustaceans & 14.3 & 23.5 & 336.05 & 34.9 & I \\
\hline 2 & Fish & 10.9 & 14.3 & 155.87 & 17.2 & II \\
\hline 3 & Amphipods & 4.3 & 2.5 & 10.75 & 1.11 & XII \\
\hline 4 & Isopods & 5.4 & 3.1 & 16.74 & 1.74 & $X$ \\
\hline 5 & Polychaetes & 4.6 & 4.3 & 19.78 & 2.05 & VIII \\
\hline 6 & Nematodes & 4.7 & 2.1 & 9.87 & 1.02 & XIV \\
\hline 7 & Phytoplankton & 5.2 & 3.5 & 18.2 & 1.89 & IX \\
\hline 8 & Zooplankton & 6.3 & 6.3 & 39.69 & 4.12 & VI \\
\hline 9 & Gastropods & 4.5 & 3.1 & 13.95 & 1.45 & XI \\
\hline 10 & Bivalves & 4.3 & 2.3 & 9.89 & 1.03 & XIII \\
\hline 11 & Sand & 6.1 & 5.1 & 31.11 & 3.23 & VII \\
\hline 12 & Detritus & 7.9 & 10.5 & 82.95 & 8.6 & IV \\
\hline 13 & Miscellaneous & 12.3 & 13.2 & 162.36 & 16.8 & III \\
\hline 14 & $\begin{array}{l}\text { Supplementary } \\
\text { feeds }\end{array}$ & 9.2 & 6.2 & 57.04 & 5.92 & V \\
\hline
\end{tabular}
Importance was recorded for Crustaceans (139.92) and the variation

Table 1: Index of Preponderance of shrimp P. monodon during March-2012. 
Citation: Varadharajan D, Soundarapandian P (2013) Science of Advance in Aqua Farming Study of Food and Feeding Habits of Jumbo Tiger Shrimp, Penaeus monodon (Fabricius, 1798) from Parangipettai, South East Coast of India. J Aquac Res Development 4: 196 doi:10.4172/21559546.1000196

Page 3 of 8

\begin{tabular}{|c|c|c|c|c|c|c|}
\hline S. No & Prey items & Occurrence & Volume & $V_{i} Q_{i}$ & 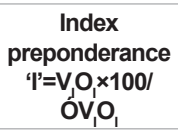 & Grading \\
\hline 1 & Crustaceans & 15.3 & 19.8 & 302.94 & 30.15 & I \\
\hline 2 & Fish & 12.7 & 16.3 & 207.01 & 20.60 & II \\
\hline 3 & Amphipods & 3.6 & 5.8 & 20.88 & 2.07 & VIII \\
\hline 4 & Isopods & 4.3 & 4.3 & 18.49 & 1.84 & $x$ \\
\hline 5 & Polychaetes & 3.5 & 2.6 & 9.10 & 0.90 & XII \\
\hline 6 & Nematodes & 4.2 & 1.9 & 7.98 & 0.79 & XIII \\
\hline 7 & Phytoplankton & 5.4 & 2.3 & 12.42 & 1.23 & $\mathrm{XI}$ \\
\hline 8 & Zooplankton & 6.2 & 3.2 & 19.84 & 1.97 & IX \\
\hline 9 & Gastropods & 2.8 & 1.3 & 3.64 & 0.36 & XIV \\
\hline 10 & Bivalves & 5.2 & 4.8 & 24.96 & 2.48 & VII \\
\hline 11 & Sand & 6.9 & 5.2 & 35.88 & 3.57 & $\mathrm{VI}$ \\
\hline 12 & Detritus & 8.1 & 12.6 & 102.06 & 10.15 & IV \\
\hline 13 & Miscellaneous & 13.5 & 14.3 & 193.05 & 19.21 & III \\
\hline 14 & $\begin{array}{l}\text { Supplementary } \\
\text { feeds }\end{array}$ & 8.3 & 5.6 & 46.48 & 4.62 & V \\
\hline
\end{tabular}

Table 2: Index of Preponderance of shrimp P. monodon during April-2012.

\begin{tabular}{|c|c|c|c|c|c|c|}
\hline S. No & Prey items & Occurrence & Volume & $V_{i} Q_{i}$ & \begin{tabular}{|c|} 
Index \\
preponderance \\
'l'= $=\mathrm{V}_{\mathrm{O}} \mathrm{O}_{\mathrm{I}} \times 100 /$ \\
OV,O
\end{tabular} & Grading \\
\hline 1 & Crustaceans & 16.4 & 21.5 & 352.60 & 34.99 & 1 \\
\hline 2 & Fish & 13.5 & 14.6 & 197.10 & 19.56 & II \\
\hline 3 & Amphipods & 4.8 & 5.2 & 24.96 & 2.47 & VII \\
\hline 4 & Isopods & 6.3 & 3.1 & 19.53 & 1.93 & IX \\
\hline 5 & Polychaetes & 4.7 & 2.7 & 12.69 & 1.25 & $\mathrm{XI}$ \\
\hline 6 & Nematodes & 5.9 & 3.2 & 18.88 & 1.87 & $x$ \\
\hline 7 & Phytoplankton & 5.7 & 1.7 & 9.69 & 0.96 & XII \\
\hline 8 & Zooplankton & 7.1 & 6.3 & 44.73 & 4.43 & $\mathrm{VI}$ \\
\hline 9 & Gastropods & 2.5 & 1.8 & 4.50 & 0.44 & XIV \\
\hline 10 & Bivalves & 4.1 & 2.3 & 9.43 & 0.93 & XIII \\
\hline 11 & Sand & 3.8 & 6.4 & 24.32 & 2.41 & VIII \\
\hline 12 & Detritus & 6.5 & 8.5 & 55.25 & 5.48 & IV \\
\hline 13 & Miscellaneous & 11.5 & 16.4 & 188.6 & 18.71 & III \\
\hline 14 & $\begin{array}{l}\text { Supplementary } \\
\text { feeds }\end{array}$ & 7.2 & 6.3 & 45.36 & 4.50 & V \\
\hline
\end{tabular}

Table 3: Index of Preponderance of shrimp P. monodon during May-2012.

of Index of Relative Importance in different food item of the month is shown in (Table 5).

The index preponderance with percentage occurrence of the different food item in conditions of the index relative importance with percentage volume for different month is presented in Tables 2 and 6. The examined guts are the maximum Index of Preponderance was observed in Crustaceans (30.15) is $1^{\text {st }}$ rank in the month of April. Fish is $2^{\text {nd }}$ ranked among the consuming food items; the Index of Preponderance (20.60) was noticed. Miscellaneous, Detritus and Supplementary feeds in that manner their occupied $3^{\text {rd }}, 4^{\text {th }}$ and $5^{\text {th }}$ places, the index of preponderance 19.21, 10.15 and 4.62 were recorded. The index of preponderances indicate that the P. monodon consumed food items their occupied places in $6^{\text {th }}, 7^{\text {th }}, 8^{\text {th }}$ and $9^{\text {th }}$ were observed the Sand (3.57), Bivalves (2.48), Amphipods (2.07) and Zooplankton (1.97) and $10^{\text {th }}, 11^{\text {th }}, 12^{\text {th }}, 13^{\text {th }}$ and $14^{\text {th }}$ ranked was recorded food items in the index of preponderances ranked indicate following the order; Isopods (1.84), Phytoplankton (1.23), Polychaetes (0.90), Nematodes (0.79) and Gastropods (0.36) respectively (Table 2). The Index of Relative Importance results are shown on the order of decreasing were ranged from $11.029-136.41$ in the month of April. The maximum of Index of

\begin{tabular}{|c|c|c|c|c|c|c|}
\hline S. No & Prey items & Occurrence & Volume & $V_{i} Q_{i}$ & $\begin{array}{c}\text { Index } \\
\text { preponderance } \\
\text { 'l'= }=\mathrm{V}, \mathrm{O}, \times 100 /_{1} \\
\mathrm{OV}_{\mathrm{I}} \mathrm{O}_{\mathrm{I}}\end{array}$ & Grading \\
\hline 1 & Crustaceans & 17.3 & 23.5 & 406.55 & 36.93 & I \\
\hline 2 & Fish & 15.8 & 15.3 & 241.74 & 21.96 & II \\
\hline 3 & Amphipods & 5.1 & 3.4 & 17.34 & 1.57 & VIII \\
\hline 4 & Isopods & 4.1 & 2.6 & 10.66 & 0.96 & XII \\
\hline 5 & Polychaetes & 3.9 & 1.7 & 6.63 & 0.60 & XIV \\
\hline 6 & Nematodes & 4.3 & 2.6 & 11.18 & 1.01 & $\mathrm{XI}$ \\
\hline 7 & Phytoplankton & 5.2 & 4.3 & 22.36 & 2.03 & VII \\
\hline 8 & Zooplankton & 4.1 & 3.2 & 13.12 & 1.19 & $x$ \\
\hline 9 & Gastropods & 3.9 & 2.6 & 10.14 & 0.92 & XIII \\
\hline 10 & Bivalves & 5.1 & 3.1 & 15.81 & 1.43 & IX \\
\hline 11 & Sand & 6.3 & 5.3 & 33.39 & 3.033 & VI \\
\hline 12 & Detritus & 5.8 & 9.5 & 55.1 & 5.00 & IV \\
\hline 13 & Miscellaneous & 12.8 & 17.3 & 221.44 & 20.11 & III \\
\hline 14 & $\begin{array}{l}\text { Supplementary } \\
\text { feeds }\end{array}$ & 6.3 & 5.6 & 35.28 & 3.20 & V \\
\hline
\end{tabular}

Table 4: Index of Preponderance of shrimp P. monodon during June-2012.

\begin{tabular}{|l|l|c|c|c|c|}
\hline S. No & Prey items & $\begin{array}{c}\text { Numbers } \\
(\%)\end{array}$ & $\begin{array}{c}\text { Volume } \\
(\%)\end{array}$ & $\begin{array}{c}\text { Frequency of } \\
\text { occurance (F) }\end{array}$ & $\begin{array}{c}\text { Index of Relative } \\
\text { Importance (N+V) } \\
\text { F=IRI }\end{array}$ \\
\hline 1 & Crustaceans & 18.3 & 21.3 & 5.71 & 139.923 \\
\hline 2 & Fish & 15.3 & 13.7 & 7.14 & 113.118 \\
\hline 3 & Amphipods & 5.2 & 6.2 & 4.76 & 34.712 \\
\hline 4 & Isopods & 6.5 & 2.5 & 10 & 31.50 \\
\hline 5 & Polychaetes & 5.9 & 3.8 & 11.9 & 51.12 \\
\hline 6 & Nematodes & 3.1 & 3.6 & 4.76 & 20.236 \\
\hline 7 & Phytoplankton & 3.6 & 6.7 & 7.14 & 51.438 \\
\hline 8 & Zooplankton & 5.1 & 4.5 & 6.19 & 32.955 \\
\hline 9 & Gastropods & 3.9 & 3.8 & 5.24 & 23.812 \\
\hline 10 & Bivalves & 4.3 & 1.9 & 7.14 & 17.866 \\
\hline 11 & Sand & 5.8 & 6.5 & 6.19 & 46.035 \\
\hline 12 & Detritus & 6.2 & 7.5 & 9.05 & 74.075 \\
\hline 13 & Miscellaneous & 10.3 & 12.8 & 6.67 & 95.676 \\
\hline 14 & $\begin{array}{l}\text { Supplementary } \\
\text { feeds }\end{array}$ & 6.5 & 5.2 & 8.1 & 48.62 \\
\hline
\end{tabular}

Table 5: The Index of Relative Importance (IRI) of the prey items of shrimp $P$ monodon during March-2012.

\begin{tabular}{|l|l|c|c|c|c|}
\hline S. No & Prey items & $\begin{array}{c}\text { Numbers } \\
(\%)\end{array}$ & $\begin{array}{c}\text { Volume } \\
(\%)\end{array}$ & $\begin{array}{c}\text { Frequency of } \\
\text { occurance (F) }\end{array}$ & $\begin{array}{c}\text { Index of Relative } \\
\text { Importance (N+V) } \\
\text { F=IRI }\end{array}$ \\
\hline 1 & Crustaceans & 15.3 & 19.8 & 4.43 & 103.014 \\
\hline 2 & Fish & 12.7 & 16.3 & 7.59 & 136.417 \\
\hline 3 & Amphipods & 3.6 & 5.8 & 8.86 & 54.988 \\
\hline 4 & Isopods & 4.3 & 4.3 & 6.96 & 34.228 \\
\hline 5 & Polychaetes & 3.5 & 2.6 & 6.33 & 19.958 \\
\hline 6 & Nematodes & 4.2 & 1.9 & 9.49 & 22.231 \\
\hline 7 & Phytoplankton & 5.4 & 2.3 & 7.59 & 22.857 \\
\hline 8 & Zooplankton & 6.2 & 3.2 & 8.86 & 34.552 \\
\hline 9 & Gastropods & 2.8 & 1.3 & 6.33 & 11.029 \\
\hline 10 & Bivalves & 5.2 & 4.8 & 5.06 & 29.488 \\
\hline 11 & Sand & 6.9 & 5.2 & 5.7 & 36.54 \\
\hline 12 & Detritus & 8.1 & 12.6 & 8.86 & 119.736 \\
\hline 13 & Miscellaneous & 13.5 & 14.3 & 7.59 & 122.037 \\
\hline 14 & Supplementary & 8.3 & 5.6 & 6.33 & 43.748 \\
\hline & feeds & & & & \\
\hline
\end{tabular}

Table 6: The Index of Relative Importance (IRI) of the prey items of shrimp $P$. monodon during April-2012. 
Citation: Varadharajan D, Soundarapandian P (2013) Science of Advance in Aqua Farming Study of Food and Feeding Habits of Jumbo Tiger Shrimp, Penaeus monodon (Fabricius, 1798) from Parangipettai, South East Coast of India. J Aquac Res Development 4: 196 doi:10.4172/21559546.1000196

Page 4 of 8

Relative Importance was recorded for Fish (136.41) and minimum was recorded in Gastropods (11.02) and the variation of Index of Relative Importance in different food item of the month is shown in (Table 6).

The index preponderance with percentage occurrence of the different food item in conditions of the index relative importance with percentage volume for different month is presented in Tables 3 and 7. Crustaceans are found to be the dominant food item in P. monodon, it is occupied the $1^{\text {st }}$ rank among various categories of food items the index of preponderance (34.99) was recorded in the month of May. The next was observed in the food item of fish were occupied $2^{\text {nd }}$ ranking the index of preponderance (19.56). The index of preponderance ranking was observed the dominant food item there occupied in 3rd Miscellaneous, $4^{\text {th }}$ Detritus and $5^{\text {th }}$ Supplementary feeds. $6^{\text {th }}, 7^{\text {th }}, 8^{\text {th }}$ and $9^{\text {th }}$ ranking of the index of preponderance was observed food item in the examined guts were Zooplankton (4.43), Amphipods (2.47), Sand (2.41) and Isopods (1.93). the index of preponderance different food item were observed the $10^{\text {th }}$ places in Nematodes $(1.87), 11^{\text {th }}$ places in Polychaetes (1.25), $12^{\text {th }}$ places in Phytoplankton(0.96), $13^{\text {th }}$ places in Bivalves $(0.93)$ and $14^{\text {th }}$ places in Gastropods $(0.44)$ (Table 3 ) respectively. The Index of Relative Importance results are shown on the order of decreasing were

\begin{tabular}{|l|l|c|c|c|c|}
\hline S. No & Prey items & $\begin{array}{c}\text { Numbers } \\
\text { (\%) }\end{array}$ & $\begin{array}{c}\text { Volume } \\
\text { (\%) }\end{array}$ & $\begin{array}{c}\text { Frequency of } \\
\text { occurance (F) }\end{array}$ & $\begin{array}{c}\text { Index of Relative } \\
\text { Importance (N+V) } \\
\text { F=IRI }\end{array}$ \\
\hline 1 & Crustaceans & 16.4 & 21.5 & 5.88 & 142.82 \\
\hline 2 & Fish & 13.5 & 14.6 & 9.56 & 153.076 \\
\hline 3 & Amphipods & 4.8 & 5.2 & 11 & 62.00 \\
\hline 4 & Isopods & 6.3 & 3.1 & 5.88 & 24.528 \\
\hline 5 & Polychaetes & 4.7 & 2.7 & 8.82 & 28.514 \\
\hline 6 & Nematodes & 5.9 & 3.2 & 7.35 & 29.42 \\
\hline $\mathbf{7}$ & Phytoplankton & 5.7 & 1.7 & 4.41 & 13.197 \\
\hline $\mathbf{8}$ & Zooplankton & 7.1 & 6.3 & 5.15 & 39.545 \\
\hline 9 & Gastropods & 2.5 & 1.8 & 5.88 & 13.084 \\
\hline 10 & Bivalves & 4.1 & 2.3 & 3.68 & 12.564 \\
\hline 11 & Sand & 3.8 & 6.4 & 7.35 & 50.84 \\
\hline 12 & Detritus & 6.5 & 8.5 & 10.3 & 94.05 \\
\hline 13 & Miscellaneous & 11.5 & 16.4 & 8.09 & 144.176 \\
\hline 14 & $\begin{array}{l}\text { Supplementary } \\
\text { feeds }\end{array}$ & 7.2 & 6.3 & 6.62 & 48.906 \\
\hline
\end{tabular}

Table 7: The Index of Relative Importance (IRI) of the prey items of shrimp $P$. monodon during May-2012.

\begin{tabular}{|l|l|c|c|c|c|}
\hline S. No & Prey items & $\begin{array}{c}\text { Numbers } \\
\mathbf{( \% )}\end{array}$ & $\begin{array}{c}\text { Volume } \\
\mathbf{( \% )}\end{array}$ & $\begin{array}{c}\text { Frequency of } \\
\text { occurance (F) }\end{array}$ & $\begin{array}{c}\text { Index of Relative } \\
\text { Importance (N+V) } \\
\text { F=IRI }\end{array}$ \\
\hline 1 & Crustaceans & 17.3 & 23.5 & 7.87 & 202.24 \\
\hline 2 & Fish & 15.8 & 15.3 & 7.09 & 124.27 \\
\hline 3 & Amphipods & 5.1 & 3.4 & 3.94 & 18.49 \\
\hline 4 & Isopods & 4.1 & 2.6 & 4.72 & 16.37 \\
\hline 5 & Polychaetes & 3.9 & 1.7 & 3.15 & 9.25 \\
\hline 6 & Nematodes & 4.3 & 2.6 & 5.51 & 18.62 \\
\hline 7 & Phytoplankton & 5.2 & 4.3 & 9.45 & 45.83 \\
\hline 8 & Zooplankton & 4.1 & 3.2 & 10.2 & 36.74 \\
\hline 9 & Gastropods & 3.9 & 2.6 & 11 & 32.50 \\
\hline 10 & Bivalves & 5.1 & 3.1 & 6.3 & 24.63 \\
\hline 11 & Sand & 6.3 & 5.3 & 9.45 & 56.38 \\
\hline 12 & Detritus & 5.8 & 9.5 & 7.87 & 80.56 \\
\hline 13 & Miscellaneous & 12.8 & 17.3 & 6.3 & 121.79 \\
\hline 14 & $\begin{array}{l}\text { Supplementary } \\
\text { feeds }\end{array}$ & 6.3 & 5.6 & 7.09 & 46.00 \\
\hline
\end{tabular}

Table 8: The Index of Relative Importance (IRI) of the prey items of shrimp $P$. monodon during June-2012.

\begin{tabular}{|l|l|l|l|l|l|l|l|}
\hline S. No & Month & $\begin{array}{c}\text { Poorly } \\
\text { feed }\end{array}$ & Medium & Heavy & $\begin{array}{c}\text { Actively } \\
\text { feed }\end{array}$ & Empty & $\begin{array}{c}\text { No of } \\
\text { shrimp }\end{array}$ \\
\hline 1 & March & 14.89 & 17.02 & 25.53 & 31.91 & 10.64 & $17 \pm 12.5$ \\
\hline 2 & April & 15.52 & 17.24 & 24.14 & 29.31 & 13.79 & $24 \pm 25.3$ \\
\hline 3 & May & 16.09 & 18.41 & 21.13 & 30.58 & 14.08 & $27 \pm 24.8$ \\
\hline 4 & June & 15.96 & 19.15 & 22.34 & 28.72 & 13.86 & $32 \pm 27.1$ \\
\hline
\end{tabular}

Table 9: Percentage of feeding intensity of shrimp during March-2012 to June2012.

\begin{tabular}{|l|l|c|}
\hline S. No & Months & Gonado somatic index (GSI) \\
\hline 1 & March & $1.09 \pm 0.23$ \\
\hline 2 & April & $1.93 \pm 0.16$ \\
\hline 3 & May & $2.75 \pm 1.24$ \\
\hline 4 & June & $2.93 \pm 1.27$ \\
\hline
\end{tabular}

Table 10: Average of Gonado somatic index (GSI) during March-2012 to June2012

ranged from 12.56-153.07 in the month of May. The maximum of Index of Relative Importance was recorded for Fish (153.07) and minimum was recorded in Bivalves (12.56) and the variation of Index of Relative Importance in different food item of the month is shown in (Table 7).

The index of preponderance with percentage occurrence of the different food item in conditions of the index relative importance with percentage volume for different month is presented in Tables 4 and 8. The index of preponderance indicated that the Crustaceans ranked $1^{\text {st }}(36.93 \%)$ in the examined gut contents of $P$. monodon during June and are followed by Fish is occurring in the index of preponderance rank of $2^{\text {nd }}(21.96 \%), 3^{\text {rd }}$ of Miscellaneous $(20.11), 4^{\text {th }}$ of Detritus (5.00), $5^{\text {th }}$ of Supplementary feeds (3.20), $6^{\text {th }}$ of Sand (3.033), $7^{\text {th }}$ of Phytoplankton (2.03), $8^{\text {th }}$ of Amphipods, $9^{\text {th }}$ of Bivalves (1.43), $10^{\text {th }}$ of Zooplankton (1.19), $11^{\text {th }}$ of Nematodes (1.01), $12^{\text {th }}$ of Isopods $(0.96)$, $13^{\text {th }}$ of Gastropods (0.92) and $14^{\text {th }}$ of Polychaetes (0.60) (Table 4) respectively. The Index of Relative Importance results are shown on the order of decreasing were ranged from $9.25-202.24$ in the month of May. The maximum of Index of Relative Importance was recorded for Crustaceans (202.24) and minimum was recorded in Polychaetes (9.25) and the variation of Index of Relative Importance in different food item of the month is shown in (Table 8).

The feeding condition of the degree of guts fullness in shrimp is correlate to feeding intensity is shown in Table 9. Generally the feeding intensity, it can varied depends the size of the species and patterns of maturity. The poorly feeding activities were observed in the late maturing and mature. The poorly feeding activity varied from 14.8916.09. The poorly feed maximum percentage (16.09) was observed in the month of May. The medium of feeding intensity were observed in early maturing. The medium of feeding activity varied from 17.0219.15. The medium of feed highest percentage (19.15) was observed in the month of June. The feeding intensity was high in immature. The heavy of feeding activity varied from 21.13-25.53. Heavy of feed maximum percentage (25.53) was observed in the month of March. Actively feed varied from 28.72-31.91. Spend and immature shrimp is an actively feed.

Actively feeding are maximum percentage of (31.91) was observed in the month of March. The occurrence of empty guts fluctuated from 10.64-14.08. The empty guts maximum of percentage (14.08) was observed in the month of May (Table 9).

The Gonado somatic index (GSI) is mainly depend the feeding intensity of the species due to data on monthly basis and the results have been presented in Table 10. The GSI ranged from $1.09 \pm 0.23$ to 
Citation: Varadharajan D, Soundarapandian P (2013) Science of Advance in Aqua Farming Study of Food and Feeding Habits of Jumbo Tiger Shrimp, Penaeus monodon (Fabricius, 1798) from Parangipettai, South East Coast of India. J Aquac Res Development 4: 196 doi:10.4172/21559546.1000196

$2.93 \pm 1.27$. The maximum of Gonado somatic index was $(2.93 \pm 1.27)$ recorded in the month of June and lowest Gonado somatic index (1.09 \pm 0.23 ) was observed in the month of March (Table 10).

\section{Discussion}

Food and feeding habits an organism is very important for maintain the species diversity and conservation. It is a regular phenomenon for living ones even aquatic or terrestrial. Those days, the humans are hunted to food from wildlife and the feral animals. There availability of vegetables, fruits and other edible plants is a major food items. It is not available easily, the searching a food from many distances site and there taken a time were high. After few days, the people got it knowledge and their cultivated paddy, other edible plants and then consuming. It is a regular base for the human in the recent days also. Demand of food, since the peoples are converted to cultivated lands from the forest and hills. Now, the cultivated land is transitioning from building. Gradually, it will grow is very fast. In the coming years food consumption is expected to rise. Usually available of human food is future in doubt when the increasing population. For the reason that, the geographical changes of the climate, patterns of rainfall, more droughts, denudation of forest, degradation of land, shortage of water, declining oil supplies, extinction of species, destruction of coastal ecosystems, pollution and production of biofuel is also a major risk for several years in food security [17]. Due to problems has been the ruthless exploitation of the earth resources. Increasing production is not enough to achieve the goal. Demand of food will grow by more than population growth and also the human diet is needs for much more income. People income is low, did not consume is nutritious food the costs of food is high. Gently is forming a dietary deficiencies disease. Food from land is not available, since the people looking for seafood [17]. Any form of sea life regarded as food by humans. It is a tasty and healthy delicious diet also. Seafood is containing high nutrition and easily digested items. Particularly, the P. monodon is contain a major elements of protein, iron, phosphorus, potassium, iodine, zinc, selenium, sodium, vitamin A, B \& D, biotin, niacin, low in saturated fat and more. Aquaculture is a main part of food security and gives as food supply, economical and export trade. It is playing a main role of species rearing, maintenance, conservation and solves the demand of food. It knows that is a naturally renewable and sustainable resource. In the evolutionary scientific days the P. monodon is a key for marine edible shrimp and the best candidate species for a relating to culture aspects. More than 15 edible shrimp is available in the aquatic ecosystem, still $P$. monodon is a remarkable winner of crustaceans and probably a most popular seafood item. Coastal people or workers and whole cultures all are depends only these crustaceans. Some of the species is not suitable for culture practices, for the reason that the size, acclimatization, survival, growth rate and climatical facts.

The giant tiger shrimp, P. monodon, is widely distributed along in the Indian Ocean. It is valuable and an economically important of commercial species. The culture of the species is much of expensive in local and foreign trade. Shrimp is alive in estuarine (juvenile), coastal (sub adult) and marine (adult) environment the range of depth from 0 $\mathrm{m}$ to $125 \mathrm{~m}$ and more. Sand and mud regions are spending for a long time. The identification of the shrimp is morphologically differ such as a color is dark, green, brown, red, grey, and the black and white banded are transversely formed within the carapace and abdomen. The rostrum well developed and toothed are having a dorsally and ventrally, 7 to 8 dorsal fin and 2-4 ventral teeth, sometimes 5 teeth is present. The differentiation of major identification character of male and female, the male is having a petasma and female is having a closed the lycum. Generally, the mating and spawning are occurring night hours and the fertilization is externally were possible. Hatching is occurring the maximum 14 hours after fertilization. Mostly, the female produces between 500,000 and 1,000,000 eggs and it can spawn several times of the year. The aquatic spider of first larvae of termed nauplii is swimming freely. The larvae do not take feed, is a non-feeding stages or planktonic ones. Zoea to mysis stage is non selective filter feeders their taking feeds for phyto and zooplankton. Post larvae stages were taking on plankton, molluscs, polychaetes and small crustaceans even as crabs, small prawn, isopods, amphipods, mysids, lucifer, mud and sand. From the post larvae through the juvenile in this stage the feeding on crustaceans, detritus, molluscs, mud and fish remains. Usually the $P$. monodon is termed bottom feeding omnivorous, the feeding on algae, seaweed, crustaceans, detritus, molluscs, sand, mud and fish parts. The shrimp have a preference for animal tissues of inhabitants origin and grow best on the food. Maximum feeds on animal origin and minimum of plant origin were observed in the study.

P. monodon is a highly carnivores is evidence of occurrence. Similar observation has been recorded by Kubo I [5] stated that Penaeus japonicus is a carnivores, mostly preferred prey item of animals origin. Ling SW et al. [18] stated that the $M$. rosenbergii as omnivorous feeder. Rao GS [4] reported that juvenile of $M$. monoceros was omnivorous as it became a carnivorous on reaching adult hood. Thomas MM [3] observed that, Penaeus semisulcatus fed on crustaceans, fishes and small animal origin is a major prey items in the Mandapam region.

Feeds are a primary energy sources for a living organisms and there obtain the energy in order to live. Shrimp is a significantly important source of food for people around in the world even caught wild and farmed is known as coastal aquaculture. The shrimp (P. monodon) is a best candidates species for aquaculture in recent scenario, it is a commercially, economically and also the diseases free of the shrimp culture is successfully formed in the global. In the closed system the meeting on shrimp face to face and to develop a strong social relationship. Some time their occur cannibalism the reason of unavailability of feeds or found empty guts. It is a playing on the game ones with other ones, suddenly as in theatrical performance starting the fight. Hence, the very aggressive ones often fighting with own kind. The strong ones attack with small ones. At the time of fighting moment was using the strong claws to a fracture mussel shells. Major serious problem is one of abnormal aggressive cannibalism. It is a habitual function especially if feed is deficient and also can arise independently. This is one of the more common problems in the farming sectors to influence the survival, performance and growth. The food and feeding habits study is very important for the species selection, site selection, stocking, maintaining and successful farming $[1,3]$. The candidate species mostly well known the feeding habits are a significantly benefit of ecosystem. Thorough knowledge about food and feeding habits is very much useful for selecting the candidate as their running a culture and the cultivable species is also providing more information on the successful farming. Hence, should be avoiding their competition of species to species. And the availability of potential prey item also easily ingestion and producing the yields are high. Feeding habits of shrimp is different when compared fish. The feeding behavior of $P$. monodon must depend on their environmental parameters such as temperature, salinity, $\mathrm{pH}$ and other factors. Naturally, the Penaeid shrimps were preferred prey item of small crustaceans, fishes, phytoplankton, zooplankton, small mollusc and detritus [1-4]. In the present study, the examined guts were recorded in Crustacean, Fish, Phytoplankton, Zooplankton, Polychaetes, Nematodes, Amphipods, Isopods, Bivalves, Gastropods, Supplementary feed, Detritus, Sand and Miscellaneous these are all the prey items is hunted before they are ingested by the 
Citation: Varadharajan D, Soundarapandian P (2013) Science of Advance in Aqua Farming Study of Food and Feeding Habits of Jumbo Tiger Shrimp, Penaeus monodon (Fabricius, 1798) from Parangipettai, South East Coast of India. J Aquac Res Development 4: 196 doi:10.4172/21559546.1000196

predator namely P. monodon. The food and feeding habits of different shrimps were earlier reported by Kubo I [5] stated of Penaeus japonicus, Thomas MM [3] have studied Penaeus semisulcatus. Rao GS [4] from Kakinada coast noticed that the M. monoceros an important food items were crustacean, fish, phytoplankton, zooplankton, polychaetes and nematodes which is formed the bulk of the diet. Ling SW et al. [18] have studied in M. rosenbergii. Kuttyamma VJ [19] has reported in some of penaeid shrimps. The earlier studies on the food and feeding habits of Penaeid shrimps pointed out that they feed on animal and plant origin such as crustacean, fish, polychaetes, nematodes, amphipods, isopods, bivalves, gastropods, supplementary feed, phytoplankton, zooplankton, detritus, sand and miscellaneous [3,4]. The report of these researchers adds support to the results of the present study. Earlier studies proved that they feed mostly on crustaceans, and small fish, which includes juveniles of their own species [3,19].

The mandible, maxilla, maxillule, lateral dactyls of maxilliped 3, antennular flagellum, and merus of periopods, periopods, maxillipeds and the branchial chamber it is an a chemoreceptors on the appendages of $P$. monodon. The foregut, midgut and hindgut are a main tract of digestive system of shrimp. Penaeid shrimp digestive processes were occurring in common phenomena. The digestive system in shrimp is basically a tube that begins at the mouth and ends at the rectum. In the present study, the digestive system of shrimp P. monodon was identifying vein or bent stick like structure is found down the shrimp back. Absent of teeth and teeth like structure were found in foregut region. It is known as cardiac or chewing intestine. They mastication their food outside their mouth is occur in the foregut site and they chew food which enters into midgut site. The hepatopancreas or phyloric stomach is function of digestive enzymes segregation, absorbs and reabsorbed ingested food items, maintain and the flow of nutrients into heamolymph and other factors. They occurs some digestive process and then into hindgut. The hindgut (intestine) is chitin-lined straight tube there occur dorsal side of cephalothorax through the abdomen to the rectum. They can occur the rest of the foods are digested and reabsorbed into the body. Excess of little foods in solids are excreted via the anus. Therefore, it can be concluded that, the digestive system of P. monodon is few feet in length which means that the food has a short distance to travel before it is digested fully.

Crustaceans were the main food item of the shrimp. All the maturity stages, the major component of diet is crustaceans was found in the examined guts during the study period. George MJ [20] have observed the gut contents of M. monoceros the maximum quantities of prey items in crustaceans. Thomas MM [3] indicated that the shrimp are consists mainly on crustaceans than others. Fish is a major food items in the young stages of shrimp. Fish remains were founds are high in the immature shrimp during the study period. The fish next to the crustaceans is the major component in the diet of $P$. monodon, which contributed $27 \%$ of the total food digested. Kubo I [5] observed high quantities of fish remains in the guts of $P$. japonicus. Hall DNF [21] remarked that Penaeid shrimp preferred fishes are a major food items. The next important food items of $P$. monodon were observed in polychaetes. They were presenting a significant quantities in all months with a small quantities were observed the examined guts of $P$. monodon during May. Available of these prey items widely distributed and associated with the bottom regions. Generally the Penaeid shrimp, when compared day time mostly taking feed at night hours. These observations are in conformity with the views expressed by Thomas MM [3] have observed that the P. semisulcatus feeding intensity are better in dark hours of the day. Rao GS [4] stated that the feeding intensity of M. monoceros was high during night hours. Unlike a predator the $P$. monodon is found under soil, when the day time or partly buried in the substratum their spending over a long time. Eldred B et al. [22] remarked that the $P$. duorarum is found under soil they can prefer food items. This kind of feeding activity is concerns like P. monodon is also a nocturnal feeder.

Mostly the organic substance is a main food resource of benthos, the suitable place of nursery, mature and breeding. Freely swimming and their spending organism is likely to have been encountered. Small sizes of polychaetes are enough to prey for the time, while they contain a small intestine. As well as the prey item is a small and dispersed. However, the food items are searching and then consuming is on a regular bases. Habitually is similar as rate of ingestion and ejection. The taken prey was allowed inside of foreguts to be filled repeatedly and again they can take more food even it can occur once per night hours. It is an evidence of $P$. monodon is a natural condition. Nematode is a predominant food item of $P$. monodon was found in all the months of study period. There was a most abundant food item in the month of May, while as considering this is a regularly available prey items. Typically is found the examined guts that the species consider can be a benthic feeder. The food and feeding habits study of $P$. semisulcatus have observed the gut contents are maximum of small animal preys is contains mainly on nematodes and polychaetes [3]. The Penaeid shrimp typically catch on mobile free swimming preys, with the phytoplankton or zooplankton that drift with water movements. Immature is actively taking mostly feed on plankton may be either phyto or zooplankton. The study indicates that the importance of both food items to this species. It is evidenced by phyto and zooplankton was observed examined guts for appreciable quantities. The primarily available of these food items shrimp can ingest certain month. They were occurring small quantities in the month of May and June. This food constituent was dominant between March and April. The ingestion of the each food items, ever since it can differ from the site on abundance and occurrence. This term agrees with earlier reported by Omori M [2] have reported that the phytoplankton is a major food items in Oplophorus quadrispinosa. Hynes HBN [8] have reported that zooplankton is one of the main food items of shrimps. The prey dominated the diet of bivalve larvae, young ones and its shells were observed in the examined guts of P. monodon. It was occurs the most explanatory variable during the study period. Gastropods were also formed the important diet components of $P$. monodon [1-3]. Detritus are forming a major item of its food [23]. Hence the detritus is dominance prey item, is an evidence of $P$. monodon was a bottom feeder. Demerits of these food items, detritus with associated microflora are also utilized at the time of growth is retarded. However, in the present study were indicating that, generally a substratum is containing sufficient amounts of the bacteria is needed to support of shrimp for growth and development. Detritus with associated bacteria sometimes are helpful for the shrimp growth and survival. Beneficial microflora is usually necessary to supply additional nutrient for each culture. There are required in large amounts of beneficial micro flora, is one of the main food item of a rearing organisms. Menon MK [1] have reported that food of shrimps consisted of detritus both animal and plant origin from inhabitants regions. Pillay TVR [9] has reported that the detritus is one of the dominant food items of Leander styliferus. Royan JP et al. [23] have conducted experiment of M. monoceros diet compositions clearly indicate that low caloric feed of detritus is a part of diet. Panikkar NK et al. [24] have identified that the food of prawn (Metapenaeus dobsoni and $P$. indicus) consists of detritus. Donaldson HA [25] has reported that the detritus is an important food item of Sergetes joponicus. The detritus contain a small quantities of nutrient is enough for species survival for long time. The supplementary feeds is 
Citation: Varadharajan D, Soundarapandian P (2013) Science of Advance in Aqua Farming Study of Food and Feeding Habits of Jumbo Tiger Shrimp, Penaeus monodon (Fabricius, 1798) from Parangipettai, South East Coast of India. J Aquac Res Development 4: 196 doi:10.4172/21559546.1000196

a regularly consuming food items during culture period, one-fourth of the volume is occur in the examined guts $[1,24]$.

P. monodon is a carnivore preferring a bottom feeding habitat, while the evidenced by sand particles are occurs in the examined guts. The sand grains are also occurred with dominant food items. Accidently it can ingested, is not directly utilized. However, sand particle were observed in the hindgut. It was a habitually seen during the study period. The sand food items were indicating the P. monodon is mainly a bottom feeder. Pillay TVR [9] have reported that, sands are consists a main prey item of prawns. Pannikar NK [26] has observed that the food of Penaeid shrimp consisted of sand particles. Moreover, the P. monodon do not ingestion for in particular prey items in the own system. However, the availability of prey item is limited that the time of food consumption is low and reducing energy wastage. If food is abundant the species caught the prey for easily, since the more time were spending for consuming, the wastage of energy is high. However the species can be a selective if food is difficult to handling process. Sometimes, they will eat whatever is available to them when it is possible absence of feeds and empty intestine hours. Habitually, in that time, be able to occur in the cause of death in these extreme cases of starvation. There are considered P. monodon is an opportunistic feeder. In the examined guts are found unidentified feed composition is high. It is a most dominant feed category. It was observed all the months of study period. Penaeid shrimps are not a selective feeder, utilizes a different type of foods. In the present study evidently indicate that, the $P$. monodon diet is differing from month to month. This term agrees with previous studies viz., Thomas MM [3] stated that the food and feeding habits of $P$. semisulcatus, Rao GS [4] investigate on the food and feeding habits of M. monoceros. Kubo I [5] have reported that the food and feeding habits of $P$. japonicus, Ling SW et al. [18] stated that the food and feeding habits of $M$. rosenbergii. Kuttyamma VJ [19] has observed that the food and feeding habits in some of Penaeid shrimps.

In nature ecosystem, most of the species are consuming in different food items. This species were introducing in closed system even aquaculture practices, there form a different disease. These kind of problem should be avoiding them know the major part of diet in particular species are very important. However, the Index of Relative Importance (IRI) is a determined the major food item of guts in each species. The gut contents of examined $P$. monodon are differing in number, length, weight and frequency of occurrences. During the study period, the analysis of gut contents of $P$. monodon revealed that the food items of shrimp ingestion were using summation of Index of Relative Importance in the month of March. It can indicate that the major prey item of P. monodon were the following order; Crustaceans (139.92) were occurring in $1^{\text {st }}$ place $>$ Fish $(113.11)$ were presenting in $2^{\text {nd }}$ place $>$ Miscellaneous (95.67) were identified in $3^{\text {rd }}$ place $>$ Detritus (74.07) were found in $4^{\text {th }}$ place $>$ Phytoplankton $(51.43)$ were observed in $5^{\text {th }}$ place $>$ Polychaetes $(51.12)$ were noticed in $6^{\text {th }}$ place $>$ Supplementary feeds (48.62) were finding in $7^{\text {th }}$ place $>$ Sand $(46.03)$ were occurring in $8^{\text {th }}$ place $>$ Amphipods $(34.71)$ were determine in $9^{\text {th }}$ place $>$ Zooplankton (32.95) were noticed in $10^{\text {th }}$ place $>$ Isopods $(31.5)$ were observed in $11^{\text {th }}$ place $>$ Gastropods $(23.81)$ were presenting in $12^{\text {th }}$ place $>$ Nematodes (20.23) were found in $13^{\text {th }}$ place $>$ Bivalves $(17.866)$ were identified in $14^{\text {th }}$ place (Table 5 ). This study agrees with previous studies viz. Hynes HBN [8] have studied in Sergestid shrimp from the eastern Gulf of Mexico. Kuttyamma VJ [19] has studied in some Penaeid prawns from the Cochin area. Maynou F et al. [27] have observed in deep-sea shrimp Aristeus antennatus from the Western Mediterranean. Karuppasamy PK et al. [28] have reported in pelagic shrimp, Oplophorus typus from the west coast of India.
The analysis of gut contents of $P$. monodon were identified different feed compositions in the month of April. The Index of Relative Importance is indicate that the major prey item of $P$. monodon were in the following order; Fish (136.41) were identified in $1^{\text {st }}$ place $>$ Miscellaneous (122.03) were occurring in $2^{\text {nd }}$ place $>$ Detritus $(119.73)$ were presenting in $3^{\text {rd }}$ place $>$ Crustaceans $(103.01)$ were noticed in $4^{\text {th }}$ place $>$ Amphipods (54.98) were observed in $5^{\text {th }}$ place $>$ Supplementary feeds (43.74) were found in $6^{\text {th }}$ place $>$ Sand $(36.54)$ were occupied in $7^{\text {th }}$ place $>$ Zooplankton (34.55) were occurring in $8^{\text {th }}$ place $>$ Isopods $(34.22)$ were found in $9^{\text {th }}$ place $>$ Bivalves (29.48) were noticed in $10^{\text {th }}$ place $>$ Phytoplankton (22.85) were determine in $11^{\text {th }}$ place $>$ Nematodes $(22.23)$ were presenting in $12^{\text {th }}$ place $>$ Polychaetes $(19.95)$ were observed in $13^{\text {th }}$ place $>$ Gastropods (11.02) were occurring in $14^{\text {th }}$ place (Table 6). The similar results can also be recorded Hynes HBN [8] have studied in Sergestid shrimp from the eastern Gulf of Mexico, Karuppasamy PK et al. [28] have reported in pelagic shrimp, Oplophorus typus from the west coast of India. Roy D et al. [29] have reported in freshwater prawn Macrobrachium choprai, Nunes AJP et al. [30] have reported in southern brown shrimp Penaeus subtilis from the Brazil. Cartes JE et al. [31] have studied in deep-sea shrimp Aristeus antennatus from the Balearic Islands.

The analysis of gut contents of $P$. monodon were identified different feed compositions in the month of May. The Index of Relative Importance is indicated that the major prey item of $P$. monodon were in the following order; Fish (153.07) were occurring in $1^{\text {st }}$ place $>$ Miscellaneous (144.17) were occupied in $2^{\text {nd }}$ place $>$ Crustaceans (142.82) were presenting in $3^{\text {rd }}$ place $>$ Detritus $(94.05)$ were occurring in $4^{\text {th }}$ place $>$ Amphipods $(62.00)$ were found in $5^{\text {th }}$ place $>$ Sand $(50.84)$ were recorded in $6^{\text {th }}$ place $>$ Supplementary feeds $(48.90)$ were noticed in $7^{\text {th }}$ place $>$ Zooplankton (39.54) were found in $8^{\text {th }}$ place $>$ Nematodes (29.42) were presenting in $9^{\text {th }}$ place $>$ Polychaetes (28.51) were occurring in $10^{\text {th }}$ place $>$ Isopods $(24.52)$ were occupied in $11^{\text {th }}$ place $>$ Phytoplankton (13.19) were presenting in $12^{\text {th }}$ place $>$ Gastropods (13.08) were observed in $13^{\text {th }}$ place $>$ Bivalves $(12.56)$ were recorded in $14^{\text {th }}$ place (Table 7). Similar study already carried out by Karuppasamy PK et al. [28] have reported in pelagic shrimp, Oplophorus typus from the west coast of India, Roy D et al. [29] have studied in freshwater prawn Macrobrachium choprai, Nunes AJP et al. [30] have reported in southern brown shrimp Penaeus subtilis from the Brazil. Cockcroft A et al. [32] have studied in Penaeid prawn Macropetasma africanus. Prakash S et al. [33] have reported in freshwater prawn Macrobrachium choprai, Cartes JE et al. [31] have studied in deep-sea shrimp Aristeus antennatus from the Balearic Islands.

The analysis gut contents of $P$. monodon were identified different feed compositions in the month of April. The Index of Relative Importance is indicated that the major prey items of $P$. monodon were in the following order; Crustaceans (202.24) were occurring in $1^{\text {st }}$ place $>$ Fish (124.27) were occupied in $2^{\text {nd }}$ place $>$ Miscellaneous (121.79) were presenting in $3^{\text {rd }}$ place $>$ Detritus $(80.56)$ were observed in $4^{\text {th }}$ place $>$ Sand $(56.38)$ were recorded in $5^{\text {th }}$ place $>$ Supplementary feeds (46.00) were found in $6^{\text {th }}$ place $>$ Phytoplankton (45.83) were occupied in $7^{\text {th }}$ place $>$ Zooplankton (36.74) were occurring in $8^{\text {th }}$ place $>$ Gastropods (32.50) were recorded in $9^{\text {th }}$ place $>$ Bivalves $(24.63)$ were observed in $10^{\text {th }}$ place $>$ Nematodes $(18.62)$ were occurring in $11^{\text {th }}$ place $>$ Amphipods (18.49) were presenting in $12^{\text {th }}$ place $>$ Isopods $(16.37)$ were noticed in $13^{\text {th }}$ place $>$ Polychaetes $(9.25)$ were determine in $14^{\text {th }}$ place (Table 8 ) respectively. Similar trends carried out by Karuppasamy PK et al. [28] have reported in pelagic shrimp, Oplophorus typus from the west coast of India, Nunes AJP et al. [30] have reported in southern brown shrimp Penaeus subtilis from the Brazil. Cockcroft A et al. [32] have studied in Penaeid prawn Macropetasma africanus, Prakash S et al. [33] have 
Citation: Varadharajan D, Soundarapandian P (2013) Science of Advance in Aqua Farming Study of Food and Feeding Habits of Jumbo Tiger Shrimp, Penaeus monodon (Fabricius, 1798) from Parangipettai, South East Coast of India. J Aquac Res Development 4: 196 doi:10.4172/21559546.1000196

reported in freshwater prawn Macrobrachium choprai. Cartes JE et al. [31] have studied in deep-sea shrimp Aristeus antennatus from the Balearic Islands.

In the present study, GSI increased were gradually from May and reached peak in June. It declined in April. The food and feeding habits of shrimp is differing from month to month. The immature shrimp to be feeding is actively. The feeding intensity of immature shrimp is high when comparing others. The feeding intensity of mature shrimp is low and the early maturing in medium of feed $[34,35]$. In the month of June, some of the mature examined specimens were observed empty guts or contains little food, in that time can occur in spawning Thomas MM, Rao GS and Kubo I [3-5]. The food and feeding habits of marine shrimp especially, black tiger shrimp P. monodon information is not available visibly. Globally, it is a popular species of culture practices, is an important species of economic activity of national development. The management of culturing period is facing a many problems even biosecurity and disease outbreaks are a critical issue. Shrimp feed is not available easily ones, since the former introducing there are availability of feeds in the culture system. The shrimp P. monodon feed is depends the climatic conditions and the pattern of ingestion and consumption rates are differ. Generally, the food selection is determined by attractant quality, feeding practice, size of the feed, moulting, water quality, nature of the food. Excess of feed and unlike feed is not good conditions for aquaculture practices. Diseases control methods are currently comes a modern shrimp feed technology. However, in the present study clearly provide information on the food and feeding habits of $P$. monodon. This information useful for culture practices in farmer and are advised to all the people if you like a good management of culture practices, the schedule of feeding and proper feed management is very essential. Whereas, the present knowledge of food and feeding habits of $P$. monodon a significantly helpful for good management of aqua farming practices. Wealth is health this study is strength for all the ones.

\section{References}

1. Menon MK (1951) The life-history and bionomics of an Indian Penaeid prawn Metapenaeus dobsoni Miers. Proc Indo-Pacific Fish Counc 3: 80-93.

2. Omori M (1975) The Biology of Pelagic Shrimps in the Ocean. Adv Mar Bio 12: $233-324$

3. Thomas MM (1980) Food and Feeding Habits of Panaeus semisulcatus de Haan at Mandapam. Indian Journal of Fisheries 27: 130-139.

4. Rao GS (1988) Studies on the feeding biology of Metapenaeus monoceros (Fabricius) along the Kakinada coast. J Mar Biol Ass India 30: 171-181.

5. Kubo I (1955) A review of the biology and systematics of shrimps and prawns of Japan. Proc Indo-Pacific Fish Counc 6: 387-398.

6. Wilcox JR, Jeffries HP (1974) Feeding Habits of the Sand Shrimp Crangon septemspinosa. Biol Bull 146: 424-434.

7. Mikulich LV (1982) The Daily Feeding Rhythm of the Grass Shrimp Pandalus kessleri (Decapoda, Pandalidae). Zool Zhurn 61: 861-866.

8. Hynes HBN (1950) The food of the Fresh water sticklebacks (Gasterosteus aculeatus and Penaeidae (Crustacea, Decapoda). Fish Publ Colon off London 17: 1- 229.

9. Pillay TVR (1952) A critique of the method of study of food of fishes. Zool Soc India 4: 195-200.

10. Verlencar XN, Desai S (2004) Phytoplankton Identification Manual. Nationa Institute of Oceanography. Dona Paula, Goa

11. Flock ME, Hopkins TL (1992) Species Composition, Vertical Distribution and Food Habits of the Sergestid Shrimp Assemblage in the Eastern Gulf of Mexico. J Crusta Biol 12: 210 -223.

12. Kasthurirangan LR (1963) A Key for the Identification of the More Common Planktonic Copepoda of Indian Coastal Waters. Coun Sci Indus Res pp. 87.
13. Wickstead JH (1965) An Introduction to the Study of Tropical Plankton. In: Hutchinson Tropical Monographs London. 160

14. Fauvel P (1927) Polychetes Sedentaires: addenda aux errantes, archiannélides, myzostomaires. Faune de France. Federation Française des Societes de Science Naturel 16: 1-494.

15. Berkeley (1952) Annelida, Polychaeta sedentaria. Canadian Pacific Fauna Fish Res Bd Canada 9b: 1-139.

16. Natarajan AV, Jhingran AG (1961) Index of Preponderance-A Method of Grading the Food Elements in the Stomach Analysis of Fishes. Indian J Fish 8: 54-59.

17. Varadharajan D, Soundarapandian P (2012) Commercially Important Crab Fishery Resources from Arukkattuthurai to Pasipattinam, South East Coast of India. J Marine Sci Res Dev 2: 110.

18. Ling SW, Merican ABC (1962) Notes on the life and habits of the adults and larval stages of Macrobrachium rosenbergii. IPFC 6: 55-60.

19. Kuttyamma VJ (1974) Observations on the food and feeding habits of some Penaeid prawns of Cochin area. Mar J Biol Ass India 15: 189-194.

20. George MJ (1976) The food and feeding of the shrimp Metapenaeus monoceros (Fabricius) caught from the backwaters. Indian J Fish 21: 495-500.

21. Hall DNF (1962) Observations on the taxonomy animal biology of some IndoWest-Pacific Penaeidae (Crustacea, Decapoda). Fish Pub Colonial off London 17: 1-229.

22. Eldred B, Ingle RM, Woodburn KD, Hutton RF, Jones H (1961) Biologica Observations on the Commercial Shrimp, Penaeus duorarum Burkenroad, in Florida waters. Flo State Bd Con Prof Ser No 3: 1-139.

23. Royan JP, Sumitra V, Wafer MVM (1977) Food conversion efficiency in the shrimp Metapenaeus monoceros (Fabricius) fed on different foods. Indian J Mar Sci 6: 100-102.

24. Panikkar NK, Menon MK (1956) Prawn Fisheries of India. Proc Indo-Pacific Fish Counc 6: 328-344

25. Donaldson HA (1975) Vertical distribution and feeding of Sergestid shrimps (Decapoda: Natantia) collected near Bermuda. Mar Biol 31: 37-50.

26. Pannikar NK (1952) Possibilities of further expansion of fish and prawn cultural practices in India. Curr Sci 21: 29-33.

27. Maynou F, Cartes J (1997) Field estimation of daily ratio in deep-sea shrimp Aristeus antennatus (Crustacea: Decapoda) in the Western Mediterranean Mar Ecol Prog Ser 153: 191-196.

28. Karuppasamy PK, Menon NG (2004) Food and Feeding Habits of the Pelagic shrimp, Oplophorus typus From the Deep Scattering Layer Along the West Coast of India. Indian J Fish 51: 17-24.

29. Roy D, Singh SR (1997) The food and feeding habits of a freshwater prawn Macrobrachium choprai. Asi Fish Sci 10: 51- 63.

30. Nunes AJP, Gesteira TCV, Goddard S (1997) Food ingestion and assimilation by the southern brown shrimp Penaeus subtilis under semi-intensive culture in NE Brazil. Aquaculture 149: 121-136.

31. Cartes JE, Papiol V, Guajardo B (2008) The feeding and diet of the deep-sea shrimp Aristeus antennatus off the Balearic Islands (Western Mediterranean) influence of environmental factors and relationship with the biological cycle. Prog Ocean 79: 37-54.

32. Cockcroft A, McLachlan A (1986) Food and Feeding Habits of the Surf Zone Penaeid Prawn Macropetasma africanus (Balss). Mar Ecol 7: 345-357.

33. Prakash S, Agarwal GP (1989) A Report on Food and Feeding Habits of Freshwater Prawn Macrobrachium choprai. Indian J Fish 36: 221-226.

34. Bravo SA, Ronquillo IA, Tiews K (1976) On the food and feeding habits of some Philippine shrimps in Manila Bay and San Miguel Bay. Philippine J Fish 14 204-212.

35. Albertoni EF, Palma-Silva C, Esteves FA (2003) Natural diet of three species of shrimps in a tropical coastal lagoon. Braz Arch Biol Technol 46: 395-403. 